\title{
THE NEW YORK STATE PSYCHIATRIC INSTITUTE AND
} HOSPITAL.

The New York State Psychiatric Institute and Hospital, which is a unit of the Medical Centre at Broadway and West 168 th Street, was opened on December 3, 1929.

Lieutenant-Governor Herbert H. Lehman, Dr. Nicholas Murray Butler, President of Columbia University, Dr. George H. Kirby, Director of the new Institute, and Dr. Frederick W. Parsons, New York State Commissioner of Mental Hygiene, Dr. William Darrach, Dean of College of Physicians and Surgeons of Columbia Medical School, Dr. Walter W. Palmer, Director of the Medical Service of the Presbyterian Hospital, and Dr. Frederick Tilney, Professor of Neurology to the College of Physicians and Surgeons, and others participated in the dedication ceremony.

In his dedicatory address, Mr. Lehman decried the lack of adequate knowledge regarding the causes, diagnosis and treatment of mental cases, and hailed the great opportunity afforded by the Institute to undertake medical and social research "on a scale and of a character never before made possible under State auspices."

Emphasizing the contribution the Institute is expected to make to preventive psychiatry and mental hygiene, Mr. Lehman referred to the need for the employment of one or more trained psychiatrists to study the problems of child maladjustment in every school system of the State.

The \$2,000,000 building rises eleven stories from the Riverside Drive level and is surmounted by a nine-story tower. The main entrance is from West 168 th Street, at the tenth floor level. In this structure, with equipment unequalled anywhere in America and probably in Europe, a programme of intensive scientific research into the causes, prevention and cure of mental diseases will be pursued, Hospitalization for both resident and out-patients and social work will be adapted to the scientific needs of the Institute.

This Institute and Hospital is the outgrowth of the Psychiatric Institute, which has been operating in a small but effective way for the past twenty-five years under the control of the State Department of Mental Hygiene. The new building and outlay, sponsored by former Governor Alfred E. Smith, are expected to magnify the thoroughness and scope of the Institute's work to an extent that will make it a world centre for psychiatric research.

During the fiscal year ended last June 30, patients in State hospitals for mental defectives increased by $\mathrm{I}, 800$ over the previous year. The ultimate aim of the Institute is to stem the inroads upon the economic life of the community caused by mental disease.

"The people of the State of New York," Dr. Kirby, the Director, interviewed, said, " have, through their elected representatives and officials, taken a liberal attitude towards the financing of scientific and investigative work in the field of psychiatry. It now becomes the problem of the scientific leaders of psychiatric thought to see correlated present-day knowledge, and to add to it in such a way that not alone will scientific knowledge be increased, but be applied in a practical way toward the prevention and the relief of mental disease throughout the State.

"One of the fine things in this effort of the State of New York is that as we succeed in helping ourselves we cannot fail to help others. This we owe to every State in the Union and every country in the world, for there is hardly a State or nation to whom we are not looking for some knowledge which we may co-ordinate to our advantage.

"I feel that I may speak for Commissioner Frederick W. Parsons of the State Department of Mental Hygiene when I say that the Department is proud to be made the custodian of this outstanding example of scientific progress which has been built by public funds, and is the first tangible evidence of broad-minded co-operation of this character between public and private enterprise, the private enterprise in this case being the Medical Centre."

Several hundred trustees and heads of New York hospitals, men and women prominent in the medical profession throughout the city and others visited the building. The first floor contains the heating plant, laundry, kitchen, pharmacy and storerooms. On the second and third floors are living accommodations for the personnel. The fourth to the ninth floors provide accommodations for 200 patients, children as well as adults. 
The out-patient department occupies a large part of the tenth and eleventh floors. Waiting rooms, offices and examination rooms are provided. Treatment facilities on these floors are so arranged that they are available to patients in the hospital as well as to the out-patient clinic.

In the tower are laboratories for research in chemistry, bacteriology, pathology and psychology. The twelfth floor is given over to the library and medical museum. In the building are an auditorium seating 150, gymnasium and two classrooms.

Dr. H. W. Potter is assistant director. Among the research associates are Dr. Armando Ferrero, specialist in neuro-pathology ; Dr. Erwin Brand, formerly of Montefiore Hospital and Home, and a leading student in metabolism; Dr. Leland Hinsie, who has made special studies in the value of psycho-analysis in treating mental disorders and in the treatment of general paralysis; and Dr. Nicholas Kopeloff, who has made a study of the influence of focal infections in mental disorders.

The complete staff will include three senior and two junior psychiatrists, a research associate in psychiatry, chemistry, bacteriology, internal medicine and psychology; three assistant research associates, a chief and five assistants in occupational therapy, a chief and three assistants in social service, a physical training instructor, a nurse and four assistants in the out-patient department, a nurse and six assistants in the hydro- and electro-therapeutic department, seventynine nurses and attendants in the ward service, and a photographer and X-ray technician.

J. R. LORD.

\section{JORDANBURN NERVE HOSPITAL AND PSYCHOLOGICAL INSTITUTE, EDINBURGH. \\ Opening of the lecture Theatre.}

A lecture theatre as part of the Jordanburn Nerve Hospital and Psychological Institute, Morningside Park, Edinburgh, was formally opened on October 15, 1929, by Mr. William Adamson, M.P., Secretary of State for Scotland.

The wide support which the new voluntary venture for treating " nerve" cases is receiving was reflected in the large and representative gathering which had assembled.

The lecture theatre, which has been built at a cost of $€ 8,000$, will be available not only for the classes of psychiatry in the University and in the Royal Colleges and School of Medicine, and for post-graduate and special courses of lectures on psychological and neurological subjects, but also for popular lectures to educate the public in the value of good mental health and the prevention of mental ill-health. It holds 250 persons comfortably; its floor is sloped to obtain a good view of the platform, which is $12 \mathrm{ft}$. wide and $34 \mathrm{ft}$. long. Much attention has been given to the acoustics, which are perfect. It has a cinema, and an epidiascope is contemplated. It is intended later to erect psychological laboratories at a cost of $£ 20,000$, and the site for these, connected up with the lecture theatre and the Royal Edinburgh Hospital for Mental and Nervous Disorders, has already been selected.

Lord Provost Sir Alexander Stevenson presided, and among those present were the Hon. Lord Murray; the Deputy-Keeper of the Signet, Mr. W. C. Johnston, W.S. ; Sir Samuel Chapman, M.P. ; Sir Patrick Ford, M.P. ; Sir Ludovic Grant ; Sir David Wallace, Mr. George Mathers, M.P. ; Sheriff Brown, K.C. ; the Very Rev. Principal Martin, D.D. ; Principal Sir Thomas Holland; Dr. R. A. Fleming, President of the Royal College of Physicians; the Dean of the Thistle, the Very Rev. Charles L. Warr ; the Very Rev. Dr. J. Harry Miller; Colonel Young, C.B.E., D.L.; Mr. H. O. Tarbolton, architect ; Mr. T. M. Gardiner, Chairman of the Board of Managers, Jordanburn Hospital ; Sir Robert Philip; Prof. George M. Robertson, Physician-Superintendent and Professor of Psychiatry, Edinburgh University; Sir Norman Walker, Prof. Lorrain Smith, Dean of the Faculty of Medicine, and other Professors in their robes.

The Lord Provost, in introducing Mr. Adamson, said that he would like to take the opportunity, on behalf of the Corporation and citizens, of expressing their high appreciation of the invaluable work carried on in the institution, under the leadership 